\title{
Clonal Propagation of Coffea arabica with Indole Butyric Acid and Acclimatization Conditions in Amazonas, Peru
}

\author{
Jardy Chichipe Oyarce $\mathbb{D}^{1},{ }^{1}$ Alina Camacho $\left(D^{2},{ }^{2}\right.$ Leidy G. Bobadilla, ${ }^{3}$ Carmen N. Vigo, ${ }^{3}$ \\ Héctor V. Vásquez, ${ }^{3,4}$ and Gelver Silva Valqui ${ }^{1}$ \\ ${ }^{1}$ Estación Experimental Agraria Amazonas, Instituto Nacional de Innovación Agraria (INIA), Ex Aeropuerto Fundo San Juan, \\ Chachapoyas 01000, Amazonas, Peru \\ ${ }^{2}$ Estación Experimental Agraria Pucallpa, Instituto Nacional de Innovación Agraria (INIA), \\ Avenida Centenario KM. 4.00-Sede Principal, Ucayali, Pucallpa 25000, Coronel Portillo, Peru \\ ${ }^{3}$ Dirección de Desarrollo Tecnológico Agrario (DDTA), Instituto Nacional de Innovación Agraria (INIA), \\ Av. La Molina 1981 La Molina, Lima 15024, Peru \\ ${ }^{4}$ Facultad de Ingeniería Zootecnista, Agronegocios y Biotecnología, \\ Universidad Nacional Toribio Rodríguez de Mendoza (UNTRM), Calle Higos Urco 342, Chachapoyas 01001, Peru
}

Correspondence should be addressed to Jardy Chichipe Oyarce; jardy06@gmail.com

Received 19 July 2021; Revised 17 September 2021; Accepted 23 September 2021; Published 6 October 2021

Academic Editor: Vijay Gahlaut

Copyright (C) 2021 Jardy Chichipe Oyarce et al. This is an open access article distributed under the Creative Commons Attribution License, which permits unrestricted use, distribution, and reproduction in any medium, provided the original work is properly cited.

\begin{abstract}
The use of hormones is important in improving the propagation process. The objective of the experiment was to identify the best dose of indole butyric acid (IBA) hormone for the rooting of coffee cuttings of the typical variety through clonal propagation in the Amazon region. The experiment was carried out in two stages. Both stages were carried out under a Completely Randomized Design (CRD). The percentage of rooting of cuttings and the number of roots were evaluated. The coffee tree clones were collected from rust tolerant elite plants. In the laboratory, the cuttings were immersed for 10 minutes in fungicide and then in five doses of IBA hormone $\left(1000,1500,2000,2500\right.$, and $\left.3000 \mathrm{mg} \mathrm{L}^{-1}\right)$ of IBA. They were then placed in a microtunnel. With the best dose obtained in stage 1 of IBA (T4: $2000 \mathrm{mg} \mathrm{L}^{-1}$ ), which achieved a rooting percentage of $52.50 \%$ and 5.8 roots on average, stage 2 was installed for the evaluation of acclimatization conditions (greenhouse and nursery). Thirty plants of the Típica variety were evaluated per treatment. Regarding the results after 90 days, the greenhouse obtained the highest values with $72.22 \%$ survival, a plant height of $9.48 \mathrm{~cm}, 4.32 \mathrm{~mm}$ stem diameter, 6.53 leaves per plant, $9.65 \mathrm{~cm}$ leaf length, and $3.83 \mathrm{~cm}$ leaf width. The IBA hormone in a controlled environment such as the greenhouse achieves good vegetative propagation for the Típica variety.
\end{abstract}

\section{Introduction}

In Peru, coffee is the main agricultural export product. According to the last National Agricultural Census-CENAGRO, approximately 223,000 families grow 425,400 ha of coffee, $91 \%$ of which are concentrated in seven regions: Junín, San Martín, Cajamarca, Cusco, Amazonas, Huánuco, and Pasco [1]. In addition, the Amazonas region ranks 17th and 18th with respect to cultivable areas with two districts that stand out: Omia and Lonya Grande with 5668.46 ha and
5457.22 ha, respectively, representing $2.6 \%$ of the national cultivated area [2].

The type of coffee grown in Peru is Coffea arabica and presents different flavor, aroma, and acidity profiles. At the national level, the most cultivated variety is the Típica variety (70\%), followed by the Caturra variety (20\%) [3]. The Típica variety is characterized for being one of the most culturally and genetically important coffees of C. arabica worldwide. In addition, it is a variety of high bearing, medium productivity, and excellent cup quality [4]. 
In recent years, this crop has suffered significant production losses due to the attack of pests and diseases, with the greatest impact being rust, which continues to affect the economy of producers [5]. On the other hand, the use of genetic material that comes from the botanical seed, as it does not present homogeneity, lowers the quality and productivity of coffee [6].

An alternative to this problem is the cloning of matrix plants resistant to rust and with good cup quality. For this, it is necessary to apply vegetative propagation techniques of coffee cuttings using hormones that induce adventitious rooting and are capable of optimizing plant growth [7]. Among these, we have auxins, which are involved in the formation and elongation of stems at the plant level [8]. The auxin with the most widespread use is IBA which is synthetically produced with great potential for the induction of adventitious roots [9].

However, despite its recognized potential, research on optimal doses for use in crops of interest such as coffee for large-scale vegetative propagation is limited [10]. Sosa-Mora et al. [11] with the combination of IBA, a biological inoculant and Pyraclostrobin 500 for three coffee hybrids, achieved superior values for the variables plant height and the number of leaves with respect to a conventional treatment based on AIB Carboxin 37.5\% + Thiram 37, 5\% fungicide methyl thiophanate $50 \%$ Truphos Ca 17\%, N 10\%, Mg 4\%, B 0.1\% F500 (Pyraclostrobin) $12.8 \%+$ Boscalid $25.2 \%$ Zn $11.6 \%$ pp-1, complexed with amino acids, carboxylic acids, and carbohydrates $\mathrm{P}$ $6 \%+$ amino acids $39.2 \%$ humic substances (0.7\%), P (8\%), N (4\%), and auxins (0.3\%). Matamoros-Quesada et al. [12] pointed out the importance of using hormones and fertilizers during the rooting and growth stage of coffee hybrid minicuttings to optimize plant performance under nursery conditions. In addition, the optimal age to achieve better-rooting percentages of cuttings with the use of hormones is in the range of 65-74 days [6].

Another factor to consider is the relationship of the coffee crop with the surrounding environment, that is, the influence of climatic factors on the development of the crop [13], with acclimatization being important, since it is a determining factor for the mass propagation of coffee plants [14]. Therefore, it is important to conduct acclimatization trials in environments such as nurseries and greenhouses.

In this sense, evaluating doses of indole butyric acid for clonal propagation of rust tolerant specialty coffee cuttings and with the best dose is important to evaluate the development of the cuttings in two acclimatization conditions emerged.

\section{Materials and Methods}

The research work was carried out in the greenhouse of the Amazonas Agrarian Experimental Station (EEA-Amazonas), located at $\mathrm{km} 7$ of the Milagro-Versalla road, District of Milagro, province of Utcubamba, Amazonas region, geographically located at latitude -5.6362795 and longitude -78.5618265 . The climate is warm with temperatures ranging from 16 to $31^{\circ} \mathrm{C}$ and an average relative humidity of $69.9 \%[15]$.
2.1. Stage 1. The plant material consisted of selected shoots from mother plants of the typical Coffea arabica variety, with good agronomic characteristics and tolerant to yellow rust [16], which were considered for rooting to give rise to new cloned plants with the same characteristics as the mother plants.

The best 4-month-old shoots were collected; the collection procedure began with the cutting of shoots of 6 pairs of leaves with a height of approximately $20 \mathrm{~cm}$ from the mother plants, using pruning shears disinfected with alcohol. They were wrapped in craft paper and placed in a Tecnopor box with damp kitchen paper to maintain humidity and turgidity for a period of six hours. Then, they were transferred to the laboratory, and the induction process for rooting was continued.

The preparation of shoots for rooting was carried out in the facilities of the in vitro propagation laboratory of the Estación Experimental Agraria Amazonas, and the following activities were performed:

To induce rooting, the cut, size, and type of shoots to be used were standardized in order to take advantage of all the cuttings collected, using shoots from the apical bud and axillary bud. The size of the cutting was $7 \mathrm{~cm}$ in length, and $50 \%$ of the leaves were cut to avoid dehydration.

The sectioned cuttings were immersed in a fungicide solution, using Attack (Cymoxanil + Mancozeb)- PM at a concentration of $2 \mathrm{~g} / \mathrm{L}$ water for a period of $10 \mathrm{~min}$. After the time lapse, they were removed and placed on a sterile table to allow the excess water to evaporate.

The preparation of the indole butyric acid (IBA) doses was carried out the day before planting cuttings in the coffee in vitro propagation laboratory of the Amazonas Agricultural Experiment Station. It was prepared based on $100 \mathrm{~mL}$ of solution for each dose, considering the weights of $0.10 \mathrm{~g}$

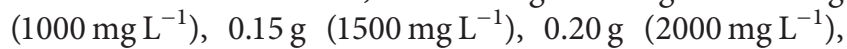
$0.25 \mathrm{~g}\left(2500 \mathrm{mg} \mathrm{L}^{-1}\right)$, and $0.30 \mathrm{~g}\left(3000 \mathrm{mg} \mathrm{L}^{-1}\right)$ of the IBA hormone weighed on an analytical balance. The IBA hormone was then placed in a $100 \mathrm{~mL}$ Erlenmeyer flask and diluted in $96^{\circ}$ alcohol. Finally, the flasks were labeled each with its respective dosage; the solution was closed and refrigerated to prevent volatilization.

\subsubsection{Immersion of Sectioned Cuttings in the Hormone and} Sowing in Trays. Each dose of indole butyric acid (IBA) hormone was transferred to beakers $(10 \mathrm{~mL}$ capacity) duly labeled, and then, the cuttings were immersed for $2 \mathrm{~s}$; they were removed and left to stand for $20 \mathrm{~s}$ on a sterile table to volatilize the excess alcohol.

Finally, holes were drilled in each cell of the tray, and $2 \mathrm{~cm}$ of the basal part of the shoot was introduced into a previously disinfected river sand-based substrate, then placed in trays (capacity of 72 cavities of $28 \times 54.5 \mathrm{~cm}$ ), and hydrated with abundant water.

Once the cuttings were planted, the trays were carefully transferred to microtunnels inside a greenhouse for rooting, and a one-minute sprinkler irrigation was applied every six hours. After that, the evaluations were carried out. 


\subsubsection{Parameters Evaluated}

(1) Rooting of Cuttings. This parameter was measured at the end of stage 1 (90 days), for which the number of rooted cuttings, with at least one root of $5 \mathrm{~mm}(0.5 \mathrm{~cm})$ or more in length, was counted and expressed in units [17].

To classify the percentage of rooted cuttings, the categories established by Del Río and Caballero [18] were taken into account, which established 5 levels according to rooting percentage: (1) very high (80-100\%), (2) high (60-80\%), (3) medium (40-60\%), (4) low (20-40\%), and (5) very low $(1-20 \%)$.

(2) Number of Roots. This variable was evaluated by directly counting the number of roots on each shoot per treatment per replicate.

2.2. Stage 2. With the best dose $\left(2000 \mathrm{mg} \mathrm{L}^{-1}\right)$ obtained from stage 1 , the cuttings were installed inside the microtunnel (used in stage 1), and weekly evaluations of the seedlings were carried out to eliminate those with signs of disease, weak, leafless, or with any other defect. This quality control was essential to be transferred after 2 weeks to two environments for evaluation: the nursery with $90 \%$ Raschel mesh shade and the greenhouse (clonal garden with temperatures between 18 and $40^{\circ} \mathrm{C}$ and humidity above $75 \%$ ) covered with an antiaphid mesh.

2.2.1. Agronomic Management of Cuttings for Both Environments. Fertilization was based on a nutrient solution with potassium nitrate $(2.4 \mathrm{~g})$, magnesium nitrate $(4.5 \mathrm{~g})$, diammonium phosphate $(4.0)$, boric acid $(0.29 \mathrm{~g})$, zinc sulfate $(0.06 \mathrm{~g})$, manganese sulfate $(0.203 \mathrm{~g})$, copper sulfate $(0.060 \mathrm{~g})$, and iron sulfate $(0.465 \mathrm{~g})$ for $100 \mathrm{~L}$ of nutrient solution [19]. Sanitary control was also carried out with fungicide and insecticide applications based on Cymoxanil + Mancozeb (50 g/20 L) and Azadirachtin A-BC$\mathrm{K}(30 \mathrm{ml} / 20 \mathrm{~L})$. One-minute sprinkler irrigations were carried out every 6 hours.

2.2.2. Parameters Evaluated. The percentage of survival was evaluated with the initial record of the seeded cuttings and the survival at the end of the research; the data were recorded as a percentage.

Evaluations of plant height and stem diameter were made at two points in time: 23 days after planting (initial height) and 73 days after the experiment (final height), using a $30 \mathrm{~cm}$ ruler from the base of the stem to the apex of the plant [20]. A digital Vernier was used to measure initial and final stem diameter.

The number of leaves per plant, leaf length, and leaf width were evaluated at two points in time: at the beginning of planting and at the end of the experiment. Leaf length was measured from the base of the petiole to the apex, and leaf width was measured at the middle of the leaf.
2.3. Experimental Design of Stage 1. For the evaluation of the data, a Completely Randomized Design (CRD) was used; the doses were considered as treatments, where 12 cuttings were selected with 10 replications per treatment, having a total of 720 cuttings (Table 1 ) which were conditioned in trays of 72 cells $(6 \times 12)$.

2.4. Experimental Design of Stage 2. It was evaluated in two environments: greenhouse (clonal garden) and nursery, which were called treatments under a Completely Randomized Design. For the survival percentage variable, the evaluation was carried out with 300 plants per environment. For the other variables, 30 plants were evaluated for each environment. For this purpose, data were recorded in evaluation cards for the subsequent systematization of the data.

2.5. Statistical Analysis for Both Stages. For the statistical analysis, the normality test and the homogeneity of variances test were performed. After verifying compliance with these two assumptions, the Analysis of Variance (ANOVA) and Tukey's multiple comparisons test at 5\% significance were performed. For the results obtained in the second stage, a similar procedure was followed, but instead of the Tukey test, the bilateral Student's $t$-test at $5 \%$ significance was used. The statistical program used was InfoStat/Professional version 2018p.

\section{Results and Discussion}

\subsection{Stage 1}

3.1.1. Rooting Percentage. In the rooting percentage evaluated 90 days after planting, the hormone dose of $2500 \mathrm{mg} \mathrm{L}^{-1}$ (T4) achieved $52.50 \pm 14.73 \%$ rooting and was significantly higher than the treatment without hormone (T0) (Figure 1(a)), which differs from that reported by Gonzalez [17] who found the best rooting value for coffee cuttings with the reference dose of $2000 \mathrm{mg} \mathrm{L}^{-1}$ of IBA hormone. The rooting value obtained by this treatment is in a medium range, so it is still favorable. However, the control reported the lowest percentage with $18.33 \pm 6.57 \%$, categorized as very low [18].

The results obtained in this research are lower than those obtained by Matamoros-Quesada et al. [12] who obtained rooting higher than $89 \%$ for three coffee hybrids (Milenio, Centroamericano, and Esperanza), installed in plastic tunnel greenhouses, with different mixtures of rooting solutions and fertilizers in conditions of Turrialba, Costa Rica. Likewise, Vásquez et al. [6] achieved higher rooting values for coffee variety Caturra (88\%) in microtunnel with IBA hormone application in the department of San Martín, Peru. This could be due to the fact that the characteristics specific to each coffee variety affect rooting in cuttings [21].

Obtaining these results indicates that the IBA hormone has a positive influence on the percentage of plant rooting when applied at the appropriate dose for the crop [22]. 
TABle 1: Description of treatments.

\begin{tabular}{lcc}
\hline IBA hormone dosage $\left(\mathrm{mg} \mathrm{L}^{-1}\right)$ & Dosage $\mathrm{g} / 100 \mathrm{ml}$ & Description \\
\hline $\mathrm{T}_{0}=0.00$ & 0.00 & Dosage $0=$ hormone-free \\
$\mathrm{T}_{1}=1000$ & 0.10 & Dosage $1=-50 \%$ of the referential \\
$\mathrm{T}_{2}=1500$ & 0.15 & Dosage $2=-25 \%$ of the referential \\
$\mathrm{T}_{3}=2000$ & 0.20 & Dosage $3=$ Referential $[17]$ \\
$\mathrm{T}_{4}=2500$ & 0.25 & Dosage $4=+25 \%$ of the referential \\
$\mathrm{T} 5=3000$ & 0.30 & Dosage $5=+50 \%$ of the referential \\
\hline
\end{tabular}

Note: $\mathrm{T}=$ treatment.

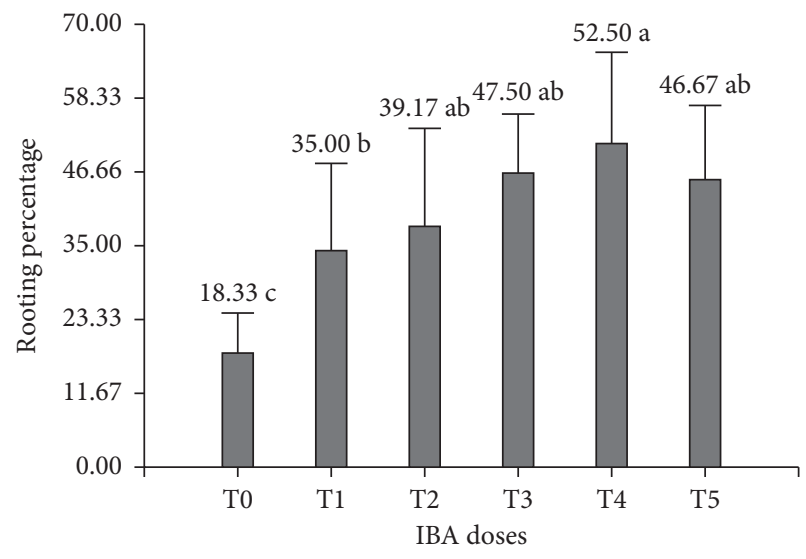

(a)

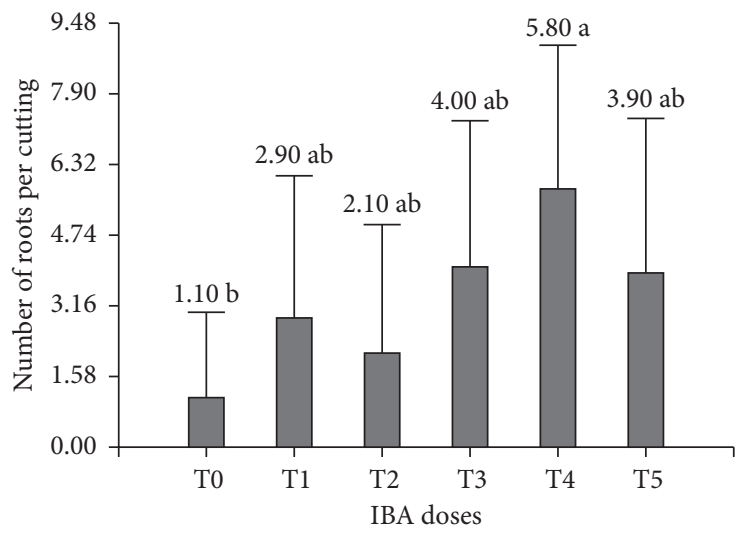

(b)

Figure 1: (a) Average percent rooting of cuttings. (b) The number of roots per cutting.

3.1.2. Number of Roots/Cutting. With respect to this variable, the T4 treatment with a dose of $2500 \mathrm{mg} \mathrm{L}^{-1}$ was the one that reported the highest number of roots with $5.8 \pm 3.19$, being statistically superior to the control treatment, which obtained the lowest number of roots/cuttings $(1.1 \pm 1.91)$ at 90 days of evaluation (Figure 1(b)).

This value is higher than that obtained by Gonzalez [17] who obtained an average of 3 roots per shoot for coffee variety Típica with Jiffy substrate and $2000 \mathrm{mg} \mathrm{L}^{-1}$ of IBA with an irrigation frequency of four times per day in nursery conditions in San Martin.

On the other hand, the data obtained in this research are superior to those obtained by Ruiz [23] who obtained an average of 1.25 roots for Coffea arabica with sand substrate and $8000 \mathrm{mg} \mathrm{L}^{-1}$ of IBA hormone in controlled environments in San Martin. Vásquez et al. [6] reported lower values than those of this research for the variety Caturra (1.33 roots/cuttings) in a greenhouse with an application of $1000 \mathrm{~m} \mathrm{~L}^{-1}$ of IBA hormone in microtunnel conditions. The differences presented with respect to this variable may be due to the fact that the IBA hormone is a plant root growth promoter that also depends on the dose and time at which it is applied [24]. The number of roots per cutting obtained for T5 (IBA dose: $3000 \mathrm{mg} \mathrm{L}^{-1}$ ) was lower than T4; this could be due to toxicity caused by an overdose of the IBA hormone [25].

\subsection{Stage 2}

3.2.1. Percentage of Survival. The results found with 300 sown coffee cuttings were $72.3 \%$ in greenhouse conditions and $63.67 \%$ in nursery conditions. Solano [26] reported survival values higher than those of this research with $90 \%$, for the Típica variety under greenhouse conditions (microtunnel), with the application of IBA hormone and sand substrate in the province of Rodríguez de Mendoza, Peru.

On the other hand, Campozano [27] also reported higher survival values in nursery conditions for Robusta coffee (Coffea canephora) with a sand substrate $(72.5 \%)$ in $\mathrm{La}$ Libertad, Ecuador. The main factor driving survival percentages was the coffee variety in each study area [28].

3.2.2. Plant Height $(\mathrm{cm})$. Regarding this variable, differences between groups were observed at the initial stage $(p=0.005)$. At the final stage, there were no significant differences. The coefficient of variability in greenhouse conditions tended to decrease from 27.38 to $20.93 \%$, while in the nursery it increased from 21.37 to $31.35 \%$.

At greenhouse level, the final average plant height was $9.48 \pm 1.99 \mathrm{~cm}$ (Figure 2); this value is higher than that obtained by Vallejos-Torres et al. [29] who obtained an 


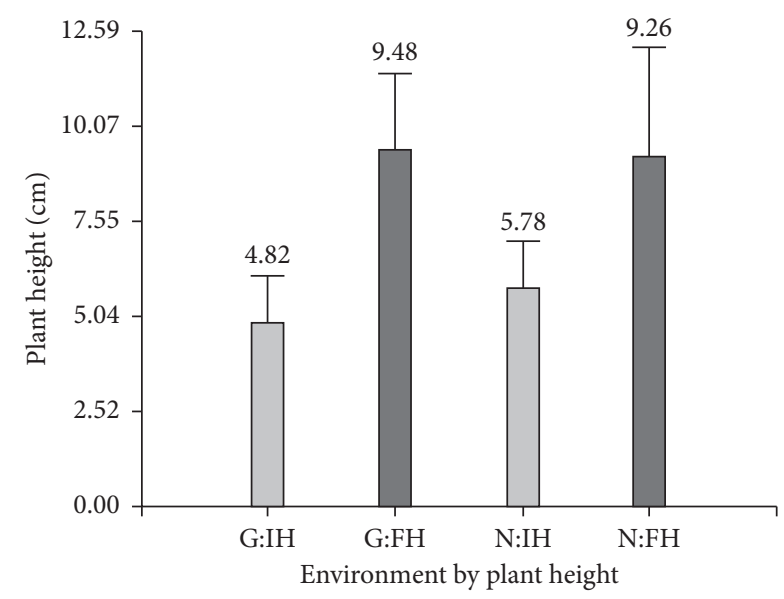

FIGURE 2: Height $(\mathrm{cm})$ of coffee plants in nursery and greenhouse. G: greenhouse, $\mathrm{N}$ : nursery, IH: initial height, and FH: final height.

average of $8.09 \mathrm{~cm}$ for the Típica variety installed in a clonal garden under microtunnel, application of IBA hormone $\left(2000 \mathrm{mg} \mathrm{L}^{-1}\right)$, and native arbuscular mycorrhizal fungi under conditions of the province of Rodríguez de Mendoza, Peru.

On the other hand, Párraga [30] reported plant height values of Robusta coffee (Coffea canephora) at 90 days of evaluation with values between 11.5 and $15.03 \mathrm{~cm}$ in nursery conditions and with the application of the rooting agent Raizplant and Hormonagro in the province of Los Ríos, Ecuador. These results are superior to those of this research in which a value of $9.26 \pm 2.90$ was obtained for nursery conditions at 73 days of evaluation. This difference may be due to the timing of the evaluation.

3.2.3. Stem Diameter ( $\mathrm{mm}$ ). With respect to stem diameter, there were significant differences between the experimental environments only in the initial stage but not in the final stage $(p=0.05)$. The coefficient of variation was higher for the greenhouse with values around $26 \%$ compared to approximately $17 \%$ variation in the nursery conditions. However, in both conditions, a decrease in the coefficient of variation was observed in the final stage.

Of the 30 plants evaluated, an average final stem diameter of $3.89 \pm 0.60 \mathrm{~mm}$ was obtained for plants in the nursery and $4.32 \pm 1.13 \mathrm{~mm}$ under greenhouse (Figure 3). Sandoval [31] for the province of Huallaga, Peru, using an asexual propagation method reported $6.2 \mathrm{~mm}$ for the Pache variety under nursery conditions, being superior to that obtained in this research. On the other hand, Tigua [32] found similar values to those of this research for the Pache variety with Kinetin hormone application at $1 \mathrm{ml} / \mathrm{L}$ with a value of $3.98 \mathrm{~mm}$ for nursery conditions in Manabí, Ecuador.

Gutiérrez and Muñoz [33] for the Caturra variety obtained a stem diameter of $1.9 \mathrm{~mm}$ at 90 days of evaluation with diammonium phosphate in a nursery environment in Honduras; these results are lower than those obtained in this research.

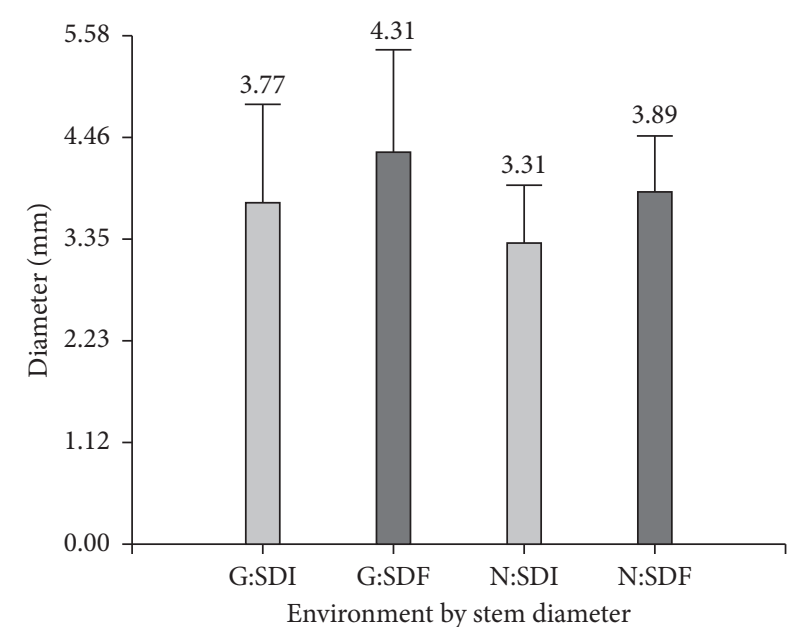

FIgURE 3: Stem diameter $(\mathrm{mm})$ of coffee plants in nursery and greenhouse. G: greenhouse, N: nursery, ISD: initial stem diameter, FSD: final stem diameter.

On the other hand, Morales [34] for Coffea canephora plants in greenhouse conditions and with the application of hormone Hormonagro and coffee husk-based substrate obtained an average of $6 \mathrm{~mm}$ at 90 days of evaluation in Ecuador; this value is higher than that obtained in this research.

3.2.4. Number of Total Leaves/Plant. The number of leaves per plant did not show significant differences between environments or evaluation stages. The coefficient of variation was similar for both evaluation environments, with a tendency to decrease in the final stage, with values around 35\% for the initial stage and 19\% for the final stage.

In the nursery, there was an increase from $2.67 \pm 0.96$ to $6.47 \pm 1.25$ leaves per plant (Figure 4). Sosa-Mora et al. [11] with three F1 coffee hybrids (Esperanza, Milenio, and H2) in nursery conditions and with the application of the same hormone for adventitious root induction (IBA) at 90 days of evaluation obtained an average number of leaves of 6.62 , results similar to those of this research.

In the greenhouse, the increase ranged from $2.77 \pm 0.97$ to $6.67 \pm 1.09$ leaves per plant (Figure 4 ). These values are lower than those reported by [34] for Robusta coffee plants (Coffea canephora) in greenhouse conditions and with agricultural soil since he obtained an average of 8.33 leaves/ plant in Ecuadorian conditions.

3.2.5. Leaf Length and Width $(\mathrm{cm})$. Regarding the variables leaf length and width, there were no significant differences between environments or between evaluation stages. The coefficient of variation for leaf length had a similar valor for both evaluation environments, since it showed a decrease in the final stage. For the leaf width variable, there was less variability in the greenhouse conditions with values around $27 \%$.

Figure 5(a) shows that, for the final evaluation, leaf length per plant increased from $5.25 \pm 1.97$ to $9.61 \pm \mathrm{cm}$. Sosa and Jimenez [35] obtained a lower average leaf length for 


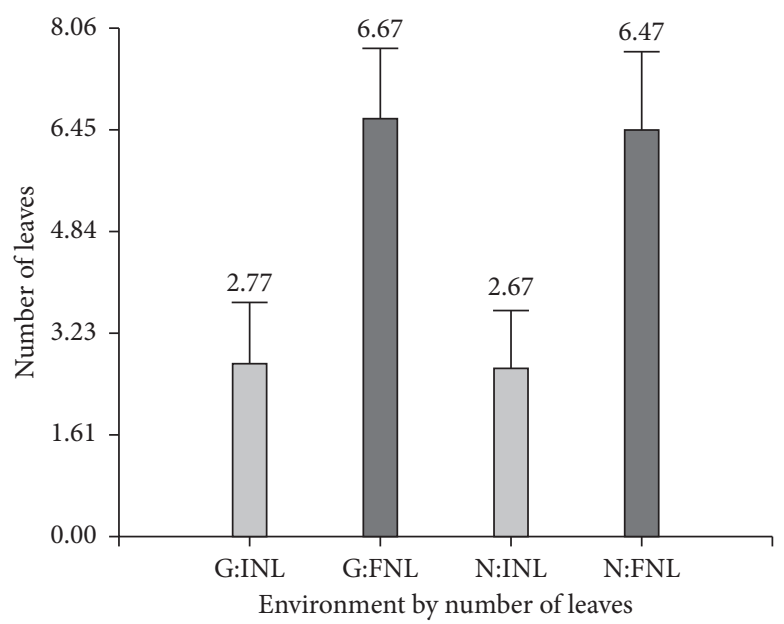

FIGURE 4: Number of total leaves/plant of coffee in nursery and greenhouse. G: greenhouse, N: nursery, INL: initial number of leaves, FNL: final number of leaves.

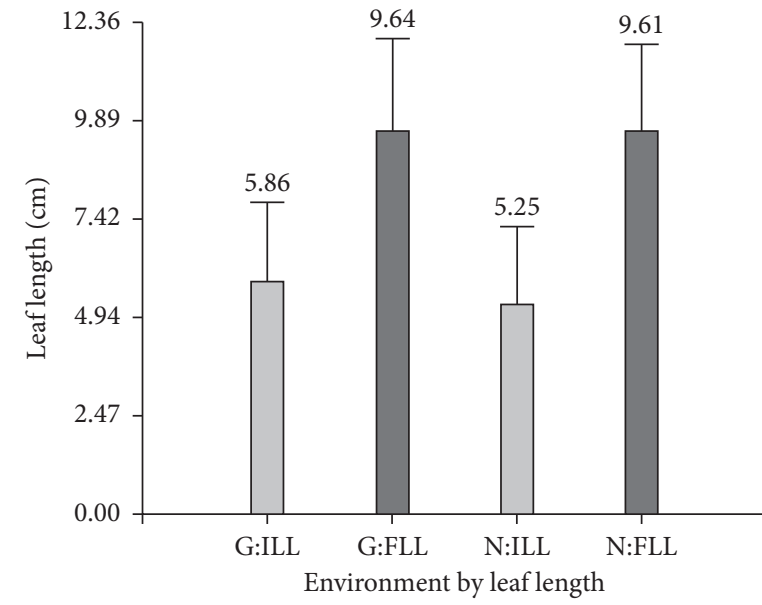

(a)

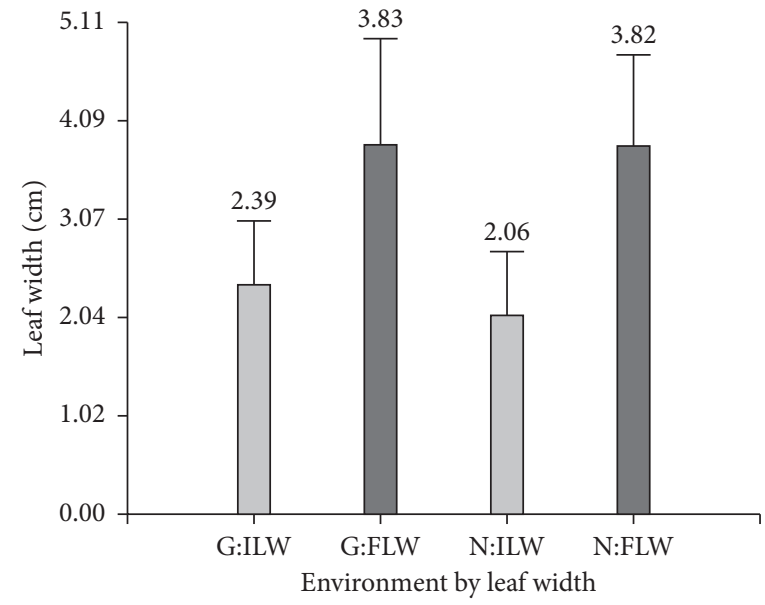

(b)

Figure 5: (a) Leaf length $(\mathrm{cm})$ and (b) leaf width $(\mathrm{cm})$ of coffee plants in nursery and greenhouse. G: greenhouse, N: nursery, ILL: initial leaf length, FLL: final leaf length, ILW: initial leaf width, and FLW: final leaf width.

Caturra coffee under nursery conditions with mycorrhizal inoculation $(8.85 \mathrm{~cm})$ in Matagalpa, Nicaragua.

Of the 30 plants evaluated, they have an average final leaf width of $3.82 \pm 0.95 \mathrm{~cm}$ for nursery plants and $3.83 \pm 1.10 \mathrm{~cm}$ in the clonal gardens under greenhouse (Figure 5(b)). Sosa and Jimenez [35] regarding the leaf width of Caturra coffee in a nursery environment with mycorrhizal inoculation obtained an average of $4.74 \mathrm{~cm}$ under conditions in Matagalpa, Nicaragua. These results are superior to those obtained in this research.

\section{Conclusions}

For stage 1, the best dose of IBA hormone was $2500 \mathrm{mg} \mathrm{L}^{-1}$ for clonal propagation of coffee cuttings, showing a higher percentage and number of roots. It would be advisable to study natural hormone sources and contrast them with the results of the present research.
As for stage 2, the best development of the coffee cuttings was observed in the greenhouse environment, presenting better plant development characteristics; since in controlled environments such as this one the relative humidity and temperature are constant, therefore, the cuttings do not suffer abrupt changes that alter their normal development. These evaluations can be complemented with substrate trials and acclimatization in the final field.

\section{Data Availability}

The data used to support the findings of this study are available from the corresponding author upon request.

\section{Conflicts of Interest}

The authors declare that there are no conflicts of interest regarding the publication of this article. 


\section{Acknowledgments}

The authors thank the Instituto Nacional de Innovación Agraria (INIA) for the funding provided for the development of this research.

\section{References}

[1] INEI (Instituto Nacional de Estadística e Informática), "IV Censo Nacional Agropecuario 2012. Sistema de consulta de datos," 2012, http://censos.inei.gob.pe/Cenagro/redatam/.

[2] C. Díaz and M. Carmen, Línea base del sector café en el Perú, Programa de las Naciones Unidas para el Desarrollo-PNUD, Lima, Peru, 2017.

[3] Andina, "Día del Café peruano: conoce cómo se cultiva y procesa el café de alta calidad," 2020, https://andina.pe/ agencia/noticia-dia-del-cafe-peruano-conoce-como-secultiva-y-procesa-cafe-alta-calidad-811699.aspx\#: :text=La\% 20planta\%20del\%20caf\%C3.

[4] IICA (Instituto Interamericano de Cooperación para la Agricultura), Manual de producción sostenible de café en la República Dominicana, Inexus Printing, Santo Domingo, Dominican Republic, 2019.

[5] Y. Pérez-Fernández, M. V. Gónzalez, E. Escamilla-Robledo, A. Cruz-León, M. Rosas-Brugada, and F. Ruiz-Espinoza, "Propuestas para la preservación de la vida en los cafetales en el municipio de Teocelo, Veracruz," Revista de Geografía agrícola, vol. 57, pp. 7-16, 2016.

[6] L. L. Vasquez, D. Ayala, G. Vallejos et al., "Edad del material vegetativo y su efecto en el enraizamiento de brotes de café (Coffea arabica) variedad caturra," Revista de Investigación Valdizana, vol. 12, no. 4, pp. 215-222, 2018.

[7] S. Damian and J. C. Hagiwara, Propagación vegetativa por medio de estacas de tallo, Ediciones INTA, Hurlingham, Argentina, 2016.

[8] E. F. George, M. A. Hall, and G. J. Klerk, "Plant growth regulators I: introduction; auxins, their analogues and inhibitoors," in Plant Propagation by Tissue CultureSpringer, Dordrecht, Netherlands, 2008.

[9] N. Iqbal, N. A. Khan, A. Ferrante, A. Trivellini, A. Francini, and M. I. R. Khan, "Ethylene role in plant growth, development and senescence: interaction with other phytohormones," Frontiers of Plant Science, vol. 8, no. 475, pp. 1-19, 2017.

[10] J. S. Alcantara Cortes, J. Acero Godoy, J. D. Sánchez Mora, and R. M. Sánchez, "Universidad Francisco de Paula Santander. Av Gran Colombia \# 12 E-96 Barrio Colsag. Cúcuta, Colombia. Enfermera. Magister en Enfermería," Nova, vol. 17, no. 32, pp. 109-129, 2019.

[11] C. Sosa-Mora, F. Mesén-Sequeira, and L. D. Jiménez-Alvarado, "Efector del ácido indolbutírico (AIB), Pyraclostrobin (F500) y un inoculante biológico sobre el enraizamiento y crecimiento inicial de estaquillas de tres híbridos F1 de café (Coffea arabica)," Agronomía Costarricense, vol. 43, no. 2, pp. 177-189, 2019.

[12] A. Matamoros-Quesada, F. Mesén-Sequeira, and L. D. Jiménezs-Alvarado, "Efecto de fitohormonas y fertilizantes sobre el enraizamiento y crecimiento de mini-estaquillas de híbridos $\mathrm{F}_{1}$ de café (Coffea arabica)," Revista de Ciencias Ambientales, vol. 54, no. 1, pp. 58-75, 2020.

[13] M. Encalada, F. Soto, D. Morales, and I. Álvarez, "Influencia de la luz en algunas características fisiológicas del cafeto (Coffea arabica L. cv. Caturra) en condiciones de vivero," Cultivos Tropicales, vol. 37, no. 4, pp. 89-97, 2016.
[14] L. Hermoso, L. Suárez-Villasmil, H. Etienne, B. Bertrand, D. Barry-Etienne, and A. Menéndez-Yuffá, "Semejanza entre el crecimiento en vivero de cafetos (Coffea arabica L.) obtenidos por embriogénesis somática y por semillas," Revista Biodiversidad Neotropical, vol. 8, no. 3, pp. 168-178, 2018.

[15] Servicio Nacional de Meteorología e Hidrología del Perú (SENAMHI), "Hydrometeorological data at the national level. Aramango Conventional Meteorological Station," 2021, https://www.senamhi.gob.pe/?\&p=estaciones.

[16] J. Arcila, F. Farfán, A. Moreno, L. F. Salazar, and E. Hincapié, "Sistemas de producción de café en Colombia," 2007, https:// www.cenicafe.org/es/publications/sistemas_de_produccion. pdf.

[17] K. A. González, "Determinación de la frecuencia de riego para el enraizamiento de brotes de café (Coffea arabica) en dos tipos de sustrato y tres concentraciones de ácido indolbutírico (AIB) en condiciones de vivero con fines de mitigación ambiental-IIAP San Martín, 2016," Thesis, p. 142, Universidad Peruana Unión, Lima, Perú, 2017.

[18] C. Del Río and J. M. Caballero, Aptitud al enraizamiento. $P$ 277-308. En: Variedades de olivo en España, Mundi-Prensa, Madrid, Spain, 2005.

[19] F. Mesén and L. D. Jiménez, Producción de clones de café por miniestacas, CATIE, vol. 130, p. 27, Turrialba, Costa Rica, 2016.

[20] T. Sanchez, M. Huamán, E. Morales, and A. Chichipe, "Dinámica de crecimiento de Pisum sativum L bajo la aplicación de ácido giberélico en la provincia de Chachapoyas- Amazonas," Revista Pakamuros, vol. 8, no. 4, pp. $45-55,2020$.

[21] I. M. Castro, O. Alves, F. Assis, and I. Wendling, "Enraizamiento de estacas juveniles de Bertholletia excelsa con diferentes concentraciones de ácido Indol-Butirico," Agrociencia, vol. 50, p. 238, 2016.

[22] C. R. Juárez-Rosete, J. A. Aguilar-Castillo, R. BugarínMontoya, C. A. Aburto-González, and G. Alejo-Santiago, "Medios de enraizamiento y aplicación de auxinas en la producción de plántulas de fresa," Cienc Tecnol Agropecuaria, Mosquera (Colombia), vol. 21, no. 1, pp. 1-13, 2020.

[23] W. Ruiz, "Propagación de café (coffea arabica 1.) Mediante el enraizamiento de rebrotes utilizando cinco dosis de ácido indolbutírico y cuatro sustratos, en ambientes controlados," Thesis, p. 98, Universidad Nacional de San Martín, San Martín. Perú, 2015.

[24] A. Báez-Pérez, L. González-Molina, E. Solís-Moya, A. Bautista-Cruz, and M. A. Bernal-Alarcón, "Efecto de la aplicación del ácido indol-3-butiríco en la producción y calidad de trigo (Triticum aestivum L.)," Revista Mexicana de Ciencias Agrícolas, vol. 6, no. 3, pp. 523-537, 2015.

[25] F. Mesén, "Enraizamiento de estacas juveniles de especies forestales: Uso de propagadores de sub-irrigación," 1998, https:// books.google.com.pe/books?hl=es\&lr=\&id=L9IOAQAAIAAJ\&o $\mathrm{i}=$ fnd\&pg $=$ PP7\&ots=3q7MCDZ7Y5\&sig=C9D0J7qokLebwMf4 YzfptmPEPHE\&redir_esc $=\mathrm{y} \# \mathrm{v}=$ onepage $\& \mathrm{q} \& \mathrm{f}=$ false.

[26] J. J. Solano, "Propagación vegetativa de café (Coffea arabica L.) por esquejes usando hormonas enraizantes y sustratos en vivero, Huambo-Rodríguez de Mendoza-Amazonas," Thesis, p. 62, Universidad Nacional Toribio Rodríguez de Mendoza de Amazonas, Amazonas, Perú, 2019.

[27] D. E. Campozano, "Eficacia de sustratos en la clonación de genotipos de café Robusta (Coffea Canephora) en manglaralto-Santa Elena," Thesis, p. 75, Universidad Estatal Península de Santa Elena. Ecuador, La Libertad, Ecuador, 2020. 
[28] R. Guamán, S. Leython, and T. Martínez, "Enraizantes naturales en Coffea canephora var. Robusta (L. Linden) A. Chev," Investigatio, vol. 12, no. 1, pp. 93-102, 2019.

[29] G. Vallejos-Torres, T. Sánchez, M. A. García, M. Trigoso, and L. A. A'revalo, "Efecto de hongos formadores de micorrizas arbusculares en clones de café (Coffea arabica) variedad Caturra," Acta Agronómica, vol. 68, no. 4, pp. 278-284, 2019.

[30] M. I. Párraga, "Estudio de la viabilidad de enraizadores en la multiplicación clonal de café robusta (Coffea canephora pierra) mediante la división longitudinal del esqueje," Thesis, p. 49, Escuela Superior Politécnica Agropecuaria de Manabí Manuel Félix López, Calceta, Ecuador, 2021.

[31] J. Sandoval, "Efecto de tres consorcios específicos de hongos micorrízicos arbusculares nativos en la biofertilización de plantas de café (Coffea arabica) variedad pache en las provincias de Moyobamba, Lamas y Huallaga de la región San Martín,” Thesis, p. 155, Universidad peruana Unión. Facultad de ingeniería y arquitectura, Tarapoto, Perú, 2019.

[32] L. E. Tigua, "Efectos de la fitohormona kinetina en el crecimiento de plántulas de la especie arábiga injertadas sobre patrón robusta en vivero," Thesis, p. 74, Universidad Estatal del Sur de Manabí, Manabí, Ecuador, 2019.

[33] E. G. Gutiérrez and M. J. Muñoz, "Evaluación de tres sistemas de producción de almácigos de café (Coffea arabica) var. Caturra," Thesis, p. 24, Universidad Zamorano, Tegucigalpa, Honduras, 2010.

[34] R. R. Morales, "Respuesta de dos fitohormonas en tres tipos de sustrato para el enraizamiento de esquejes de café robusta (Coffea canephora) en el cantón Lago Agrio," Thesis, p. 105, Universidad Tecnológica Equinoccial, Quito, Ecuador, 2013.

[35] H. J. Soza and O. A. Jiménez, "Validación de dos dosis de micorrizas en el desarrollo de las plantas en vivero de café (Coffea arabica L.), variedad Caturra en dos localidades del municipio de Jinotega, periodo 2017-2018," Thesis, p. 92, Universidad Nacional Autónoma de Nicaragua, Managua, Matagalpa, Nicaragua, 2018. 